\title{
Transcriptional control and hormonal response of thermogenic fat
}

\author{
Margo P Emont ${ }^{1,2}$, Hui $\mathrm{Yu}^{1}$ and Jun $\mathrm{Wu}^{1,2}$ \\ ${ }^{1}$ Life Sciences Institute, and ${ }^{2}$ Department of Molecular and Integrative Physiology, University of Michigan, \\ 210 Washtenaw Avenue, LSI, RM5115A, Ann Arbor, Michigan 48109, USA
}

Correspondence should be addressed to $\mathrm{Ju}$

Email wujunz@umich.edu

\begin{abstract}
Obesity and its associated metabolic diseases present a major public health problem around the world. The discovery that thermogenic fat is active in adult humans has sparked a renewal of interest in the study of its development and function and in the feasibility of using modulators of thermogenesis to work against obesity. In recent years, it has been shown that there are at least two distinct types of thermogenic fat cells: brown and beige fat. In this review, we discuss the transcriptional mediators of thermogenesis and the signaling molecules that regulate thermogenic cells. We also review the effects of thermogenic fat activation on whole-body metabolic parameters and evaluate the increasing evidence that activating thermogenesis in humans can be a viable method of ameliorating obesity. In these discussions, we highlight targets that can potentially be stimulated or modified in anti-obesity treatments.
\end{abstract}

\author{
Key Words \\ - obesity \\ - diabetes \\ - brown adipocyte \\ - beige adipocyte \\ - adaptive thermogenesis
}

\section{Introduction}

Obesity is a major health problem in the United States and around the world. Over one-third of adults in the United States (Ogden et al. 2014) and $11 \%$ of adults worldwide are obese (WHO: www.who.int/mediacentre/factsheets/ fs311/en). A number of conditions including heart disease, type 2 diabetes, and some cancers are more prevalent in obese individuals, and worldwide $\sim 3.4$ million deaths each year are related to obesity (WHO: www.who.int/media centre/factsheets/fs311/en). Obesity is characterized by an excessive amount of lipid accumulation in fat cells; as a result there has been a continual effort to find cellular processes and molecular targets in fat that can be manipulated in anti-obesity treatments.

Three types of fat cells have been identified to date (Rosen \& Spiegelman 2014). White adipocytes are primarily used for energy storage; they contain a large lipid droplet and few cellular organelles. In contrast, brown adipocytes are primarily a site for adaptive thermogenesis which, unlike the obligatory thermogenesis that is a natural byproduct of metabolic processes, is activated in response to cold stimulation (Himms-Hagen 1989). Brown adipocytes contain multiple small lipid droplets and a number of mitochondria, which express uncoupling protein 1 (UCP1), a major component of the thermogenic program and a specific marker of thermogenic adipocytes (Cannon \& Nedergaard 2004). UCP1 is activated by long-chain fatty acids and increases the conductance of the inner mitochondrial membrane, causing the mitochondria to produce heat at the expense of ATP production efficiency (Fedorenko et al. 2012). While overabundance of white fat is the defining characteristic of obesity and contributes to the

Published by Bioscientifica Ltd 
development of metabolic disease, brown fat in fact works to counteract obesity by converting chemical energy into heat as opposed to storing it as lipid (Rosen \& Spiegelman 2014). Brown fat is primarily found interscapularly in rodents and arises from MYF5 ${ }^{+}$stem cells that can also differentiate into skeletal myocytes (Seale et al. 2008). 'Beige' or 'brite' fat is a newly identified type of fat that is located in white adipose tissue and arises from MYF5 ${ }^{-}$ stem cells but has an inducible thermogenic program (Petrovic et al. 2010, Wu et al. 2012). We will refer to thermogenic cells in white fat depots as beige cells and to the process of the activation of thermogenic fat cells in white fat depots as 'beiging' in this review. It is conceivable that other types of fat exist in addition to white, brown, and beige fat. Recent work on marrow adipose tissue, for example, has begun to characterize the distinctive functions of these unique fat cells that are not seen in currently identified types of fat (Cawthorn et al. 2014, Scheller \& Rosen 2014).

Adaptive thermogenesis in fat is activated by cold exposure mainly through the signaling of catecholamines secreted by the sympathetic nervous system (Cannon \& Nedergaard 2004). The sympathetic nervous system primarily signals through the $\alpha$ and $\beta 1-3$ adrenergic receptors (AR), consequently in $\beta$-less mice, which lack all isoforms of the $\beta$-adrenergic receptor, the brown fat depot comprises cells with large lipid droplets and blunted UCP1 expression (Bachman et al. 2002). The $\beta$-ARs are G-protein-coupled receptors that activate adenylyl cyclase by stimulation, and increase the levels of intracellular cAMP. This leads to the phosphorylation of protein kinase A (PKA), which in turn activates the p38 MAP kinase (MAPK) pathway and induces cAMP response-element binding protein (CREB)-mediated upregulation of UCP1 (Cannon \& Nedergaard 2004). Studies have begun to show that therapeutics that act centrally can affect thermogenesis, for example a glucagon-like peptide-1 (GLP1) receptor agonist works in the CNS to activate brown adipose tissue and may increase resting energy expenditure in humans (Beiroa et al. 2014). $\beta$-adrenergic signaling may not be the only pathway for cold-induced activation of thermogenic fat. Ye et al. (2013) showed that cultured, mature, adipocytes can upregulate thermogenesis in response to cold exposure, suggesting that there is also a cell autonomous cold-sensing mechanism in fat cells. This implies that there may be unexplored pathways that function in parallel with $\beta$-AR signaling to activate coldinduced thermogenesis.

This review focuses on the transcriptional control of thermogenic genes and the signaling beyond the sympathetic nervous system that regulates both brown and beige fat function. We also discuss the effects that thermogenic fat activation may have on systemic metabolism in humans, and highlight molecules that have begun to be tested as drug targets.

\section{Transcriptional control of thermogenic fat}

The cascades mediated by a number of transcriptional factors and cofactors tightly control the adipogenic process. The unique mechanisms that regulate thermogenic fat are much less well understood. In the following section, we discuss the factors that contribute to the development of thermogenic cells and the activation of the thermogenic program (Fig. 1).

\section{Peroxisome proliferator-activated receptor gamma}

Peroxisome proliferator-activated receptor gamma $(\operatorname{PPAR} \gamma)$ is the master regulator of adipogenesis; ectopic expression of PPAR $\gamma$ stimulates the differentiation of fibroblasts into adipocytes (Tontonoz et al. 1994). PPAR $\gamma$ is a nuclear receptor that heterodimerizes with the retinoid X receptor (RXR) to induce transcription of genes related to the adipogenic program (Ahmadian et al. 2013). In addition to its central role in adipogenesis, PPAR $\gamma$ has been shown to be important in the regulation of thermogenesis. Chronic stimulation of adipocyte cultures with $\operatorname{PPAR} \gamma$ agonists results in an induction of the thermogenic program (Fukui et al. 2000, Wilson-Fritch et al. 2004, Petrovic et al. 2010). Ongoing research is beginning to elucidate the molecular mechanisms by which PPAR $\gamma$ regulates thermogenesis. A mice model with a point mutation in Ppary was found to have normal development of adipose tissue but has defective thermogenesis (Gray et al. 2006) and more recently it has been shown that SIRT1-dependent deacetylation of PPAR $\gamma$ plays a role in the upregulation of thermogenic genes (Qiang et al. 2012). It has also been proposed that stabilization of PRD1-BF1-RIZ1 homologous domain containing 16 (PRDM16) through the action of PPAR $\gamma$ agonists may contribute to the induction of thermogenesis (Ohno et al. 2012). These studies have begun to provide mechanistic insights into our understanding of how PPAR $\gamma$ regulates the function of thermogenic fat.

\section{PPAR $\gamma$ coactivator 1 alpha}

The PPAR $\gamma$ coactivator 1 (PGC1) family of proteins are coactivators that are key inducers of mitochondrial

Published by Bioscientifica Ltd 


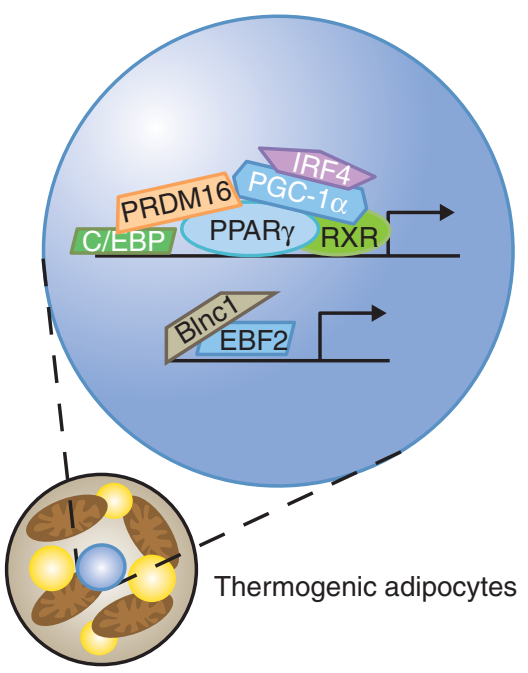

Figure 1

Transcriptional regulators of the thermogenic program. The PPAR $\gamma / R X R$ heterodimer plays a key role in regulating the development of all adipocytes. In thermogenic adipocytes (left), it also plays a major role in the regulation of the thermogenic program. A number of coactivators interact with PPAR $\gamma$, including PGC1 $\alpha$ which is regulated in part by IRF4, and PRDM16, which interacts with both PPAR $\gamma$ and C/EBP $\beta$ to drive

biogenesis (Puigserver 2005). The first PGC1 protein to be identified is PGC1 $\alpha$, which was isolated in a yeast two-hybrid screen for PPAR $\gamma$-interacting proteins in brown fat (Puigserver et al. 1998). Both PGC1 $\alpha$ and a closely related family member, PGC1 $\beta$, are regulators of the thermogenic program. Brown fat cells from $P g c 1 \alpha$ knockout animals have a decrease in cAMP-induced thermogenesis, and loss of both PGC1 $\alpha$ and PGC1 $\beta$ in brown fat cells reduces basal levels of thermogenesis (Uldry et al. 2006). In addition, while $P g c 1 \beta$-knockout mice have a compensatory increase in PGC1 $\alpha$ expression, there is a reduction in thermogenic gene expression in the brown fat of those animals (Lelliott et al. 2006). Recently, interferon regulatory factor 4 (IRF4) has been shown to interact with PGC1 $\alpha$ to mediate thermogenesis. In the model of IRF4 overexpression in UCP1- positive cells, thermogenesis is activated in the brown fat of the transgenic animals compared with the controls. In addition, a Ucp1-CRE driven Irf4-knockout results in cold intolerance and a reduction in thermogenic gene expression (Kong et al. 2014). PGC1 $\alpha$ has also been shown to induce the expression of cell death-inducing DFFA-like effector (CIDEA), a regulator of UCP1 function. This interaction is inhibited through direct interaction of PGC1 $\alpha$ with the corepressor receptor-interacting protein 140 (RIP140) (Hallberg et al. 2008). RIP140 had previously been reported to inhibit mitochondrial biogenesis and the expression of

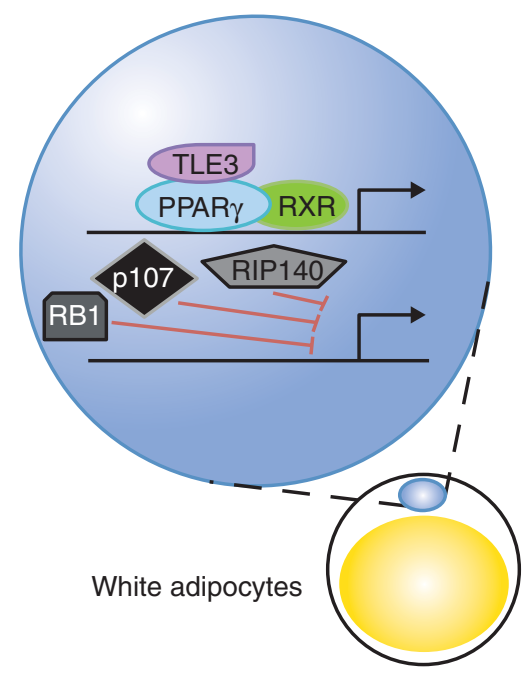

thermogenesis. Other transcriptional regulators of thermogenesis include EBF2, which forms a ribonucleoprotein complex with Blinc1 to upregulate thermogenic genes. In white adipocytes (right) the PPAR $\gamma /$ RXR heterodimer instead interacts with TLE3, leading to the expression of white fat-selective genes. RB1, p107, and RIP140 also work in white adipocytes to inhibit the transcription of thermogenic genes.

thermogenic genes such as Ucp1 (Christian et al. 2005, Powelka et al. 2006). PGC1 $\alpha$ is also negatively regulated by retinoblastoma protein (RB1) and its closely related family member p107. RB1 has been shown to suppress PPAR $\gamma$ signaling and promote osteogenic differentiation, and p107-knockout mice have increased expression of PGC1A and UCP1 in both brown and white fat depots (Scime et al. 2005, Calo et al. 2010). These studies show that various interacting proteins can regulate PGC1A function in the mediation of thermogenic gene expression.

\section{PRD1-BF1-RIZ1 homologous domain containing 16}

PRDM16 is a zinc finger protein that is an important regulator of thermogenic fat. Ectopic expression of PRDM16 in cultured fibroblasts and in vivo results in thermogenic adipocyte differentiation (Seale et al. 2007). It was subsequently found that PRDM16 expression in precursor cells determines cell fate, Prdm16-knockdown in primary brown fat precursor cells results in the differentiation of those cells into skeletal myotubes while overexpression of PRDM16 in skeletal muscle precursor cells results in brown adipocyte differentiation (Seale et al. 2008). The mechanism by which PRDM16 determines precursor cell fate was later shown to be controlled in part by a transcription complex consisting of PRDM16 and CCAAT/enhancer-binding protein $\beta$ (C/EBP $\beta$ ) (Kajimura

Published by Bioscientifica Ltd 
et al. 2009). Further in vivo models showed that fat specific PRDM16 overexpression results in improved metabolic function and less weight gain in high fat diet-fed mice (Seale et al. 2011) and knocking out Prdm16 results in a loss of the thermogenic program in both brown and beige fat (Cohen et al. 2014, Harms et al. 2014). Ongoing work is beginning to characterize the transcriptional complex that interacts with PRDM16 to promote thermogenesis (Dempersmier et al. 2015).

\section{Early B-cell factor 2}

Early B-cell factor 2 (EBF2) is a helix-loop-helix transcription factor that regulates B lymphocytes and neuronal genes (Hagman et al. 1993), and has been shown to regulate adipogenesis (Akerblad et al. 2002, Jimenez et al. 2007). More recently, EBF2 has also been shown to play a role in the regulation of the thermogenic program in brown and beige adipocytes. A 2013 study used models of Ebf2-knockout and overexpression to demonstrate that EBF2 helps to recruit PPAR $\gamma$ to the promoter regions of thermogenic target genes and, with PPAR $\gamma$, activates the transcription of PRDM16. Ebf2-knockout mice present defective brown fat development (Rajakumari et al. 2013) and recent studies have indicated that EBF2 may also be involved in the regulation of beige fat function (Wang et al. 2014a). The identification of brown fat long noncoding RNA 1 ( $B \ln c 1$ ) has provided insights into the mechanisms of EBF2 action. Blnc1 was shown to be an important component of the EBF2 ribonucleoprotein complex (Zhao et al. 2014). The adipocytes that overexpress BLNC1 express thermogenic genes at a higher level than controls at both basal and stimulated states, underlining the role of the $E b f 2$ transcription complex in the regulation of thermogenesis (Zhao et al. 2014).

\section{Transducin-like enhancer of split 3}

Transducin-like enhancer of split 3 (TLE3) is a groucho family co-repressor that was identified as a modulator of adipogenesis in a high throughput cDNA screen (Villanueva et al. 2011). It was found that PPAR $\gamma$ directly drives Tle 3 expression and that the TLE3 protein binds to $\operatorname{PPAR} \gamma$ and uncharacteristically acts as a co-activator to promote differentiation (Villanueva et al. 2011). Subsequent work has shown that TLE3 is actually a white fat selective protein; overexpression of TLE3 in fat leads to a decrease in thermogenic gene expression, and a fatspecific Tle3-knockout has an increase in the thermogenic response to cold exposure (Villanueva et al. 2013).
Co-expression experiments revealed that TLE3 and PRDM16 'compete' to bind to PPAR $\gamma$ and the resulting distinct transcription complexes determine the expression of either lipid storage 'white fat-specific' genes or thermogenic fat specific genes (Villanueva et al. 2013).

\section{SMAD}

Transforming growth factor $\beta$ (TGF $\beta$ ) signaling through SMAD proteins has been shown to negatively regulate adipogenesis (Zamani \& Brown 2011). A Smad3-global knockout mouse is resistant to diet-induced obesity, and there is increased UCP1 expression in the adipose tissue of these animals compared with controls (Yadav et al. 2011). Similarly, treating WT animals with exogenous TGF $\beta 1$ reduced thermogenic gene expression in fat (Yadav et al. 2011). Zinc finger protein 423 , a transcriptional regulator of SMAD proteins, has been identified as playing a key role in preadipocyte fate commitment (Gupta et al. 2010). The therapeutic potential of targeting TGF $\beta$ signaling has been explored using a dominant-negative activin receptor type IIB fusion protein that promotes thermogenesis through binding of TGF $\beta$ and inhibition of downstream signaling (Koncarevic et al. 2012).

\section{Secreted molecules and signaling in thermogenic fat}

While sympathetic signaling is the most understood pathway for the activation of adaptive thermogenesis, new research has focused on identifying other secreted factors that can activate thermogenic fat, both to gain a greater understanding of the regulation of the thermogenic program and to identify potential targets for drug discovery (Fig. 2).

\section{FGF family}

Fibroblast growth factor (FGF) family members, such as FGF1 and FGF15/19, have been found to be contributing to the regulation of glucose homeostasis and the beiging of white fat (Fu et al. 2004, Jonker et al. 2012). FGF21 is the family member most well studied in metabolism; it has been shown to regulate glucose homeostasis, lipid metabolism, insulin sensitivity, ketogenesis, and the prevention of cardiovascular disease (Kharitonenkov et al. 2005, Badman et al. 2009, Lin et al. 2013, Itoh 2014, Patel et al. 2014). FGF21 is mostly produced in and released from the liver; however, thermogenic activation also increases FGF21 expression in subcutaneous and brown adipose tissue (Hondares et al. 2011, Fisher et al. 2012).

Published by Bioscientifica Ltd 


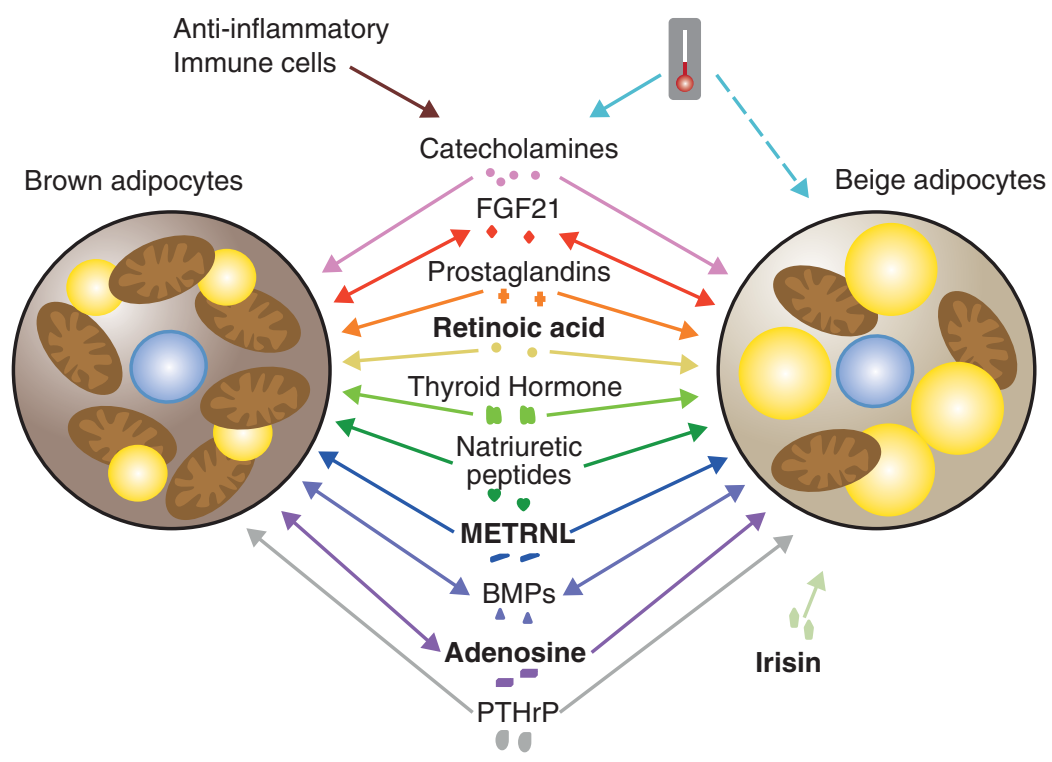

Figure 2

The regulation of thermogenic fat cells by secreted factors. A number of secreted factors regulate the thermogenic program in brown and beige cells. Cold exposure induces production of catecholamines from the sympathetic nervous system (solid teal line) and may also activate beige fat through a cell autonomous mechanism (dashed teal line). Anti-inflammatory macrophages can also produce catecholamines. FGF21, PG, RA, NPs, thyroid hormone, METRNL, BMPs, adenosine, and PTHrP regulate

Ongoing research is investigating the differential roles of liver- and adipose tissue-derived FGF21 in the regulation of energy homeostasis (Markan et al. 2014). Systemic administration of FGF21 increases the expression of UCP1 (Coskun et al. 2008) and genetic ablation of Fgf21 impairs the ability of animals to adapt to cold exposure (Fisher et al. 2012). Though FGF21 is not expressed in the CNS, it can cross the blood-brain barrier to induce sympathetic nerve activity and thus centrally increase thermogenic gene expression and energy expenditure (Owen et al. 2014). Recent studies have revealed that adiponectin at least partially mediates the effects of FGF21 on energy expenditure and insulin action (Holland et al. 2013, Lin et al. 2013). Due to the beneficial effects of FGF21 in metabolism, there has been considerable interest in the development of an FGF21 analog drug, the successful production of which could potentially provide new strategies to improve metabolic health in humans (Kharitonenkov \& Adams 2014).

\section{COX2 and prostaglandins}

Cyclooxygenase-2 (COX2) is an enzyme that synthesizes prostaglandins (PGs) in response to stimuli such as thermogenesis in brown and beige cells. In addition, the myokine irisin regulates thermogenesis in beige fat. FGF21, some BMPs, and adenosine have also been shown to be secreted by thermogenic adipocytes. To differentiate the factors that work in concert with central activation of thermogenesis and through $\beta$-adrenergic signaling from those that work through independent pathways, these independent factors, RA, adenosine, Irisin, and METRNL, have been bolded.

inflammatory signaling (Ricciotti \& FitzGerald 2011). In 2010, two independent studies reported the induction of COX2 in white fat depots upon cold-exposure or $\beta$-adrenergic stimulation (Madsen et al. 2010, Vegiopoulos et al. 2010). Pharmacological inhibition or genetic ablation of COX2 diminishes the cold or $\beta$-AR activation-induced beiging of white adipose tissue (Madsen et al. 2010, Vegiopoulos et al. 2010). Overexpression of COX2 has been shown to increase UCP1 expression in adipose tissue, elevate energy expenditure, and reduce weight gain (Vegiopoulos et al. 2010). More recently, prostaglandin $\mathrm{E}_{2}$ $\left(\mathrm{PGE}_{2}\right)$ and the enzyme that synthesizes it, microsomal synthase-1 (mPGES1), were shown to play a role in the development of beige fat (Garcia-Alonso et al. 2013).

\section{Retinoic acid}

Retinoic acid (RA), the active derivative form of vitamin A, is mainly synthesized intracellularly from retinaldehyde (Rald) by retinaldehyde dehydrogenases (RALDHs) (Niederreither \& Dolle 2008). Studies have suggested that RA, Rald, and RALDHs, all play functional roles in the regulation of thermogenic gene expression. It has long been recognized that RA induces UCP1 expression both in

Published by Bioscientifica Ltd 
cultured brown adipocytes and in brown adipose tissue (Puigserver et al. 1996). In mouse embryonic fibroblastderived adipocytes, UCP1 expression is highly elevated upon all-trans RA stimulation in a p38 MAPK-dependent manner (Mercader et al. 2010). Rald has also been implicated in the induction of the thermogenic program; Plutzky and colleagues have shown that Raldh1-knockout mice have elevated levels of Rald and exhibit increased energy expenditure, improved insulin sensitivity, and resistance to diet-induced obesity (Ziouzenkova et al. 2007). Later studies demonstrated that the beneficial metabolic effects of Rald signaling likely act through a PGC1 $\alpha$-mediated pathway (Kiefer et al. 2012).

\section{Thyroid hormone}

Thyroid hormones are produced by the thyroid and bind to thyroid hormone receptors (TR) $\alpha 1-2$ and $\beta 1-2$ to affect to growth and metabolism in target tissues throughout the body, including bone, liver, heart, and fat (Yen 2001). Thyroxine, or $\mathrm{T}_{4}$ thyroid hormone, comprises the majority of thyroid output and deiodinases at peripheral tissues, such as the liver and kidney, removes the $5^{\prime}$ iodine on $\mathrm{T}_{4}$ to form the metabolically active form of thyroid hormone, triiodothyronine $\left(\mathrm{T}_{3}\right)$ (Yen 2001). $\mathrm{T}_{3}$ is responsible for increasing the metabolic rate and it has been shown to work in concert with norepinephrine to induce transcription of $U c p 1$ in the brown adipose tissue of rats in vivo (Bianco et al. 1988). Later studies showed that the treatment of primary fetal brown adipocytes from rats with $\mathrm{T}_{3}$ increases $U c p 1$ transcription and stabilizes $U c p 1$ mRNA (Guerra et al. 1996). The ability of $\mathrm{T}_{3}$ to induce thermogenesis was shown to be dependent on the TR isoform that it signals through; the TR $\beta 1$-specific agonist GC1 stimulates UCP1 expression but a TR $\alpha 1$ agonist does not (Ribeiro et al. 2001, Martinez de Mena et al. 2010). While thyroid hormone can directly activate the thermogenic program in fat cells, $T_{3}$ signaling in the hypothalamus through AMPK also works to activate the CNS to induce thermogenesis via $\beta 3$-AR signaling (Lopez et al. 2010).

\section{Natriuretic peptides}

The natriuretic peptides (NPs) are a family of cardiac and vascular-derived hormones that regulate sodium homeostasis in blood and urine. There are three main types of NPs; atrial natriuretic peptide (ANP), and B- and C-type natriuretic peptides (BNP and CNP) (Zois et al. 2014). In addition, there are two major classes of NP receptors:
NP receptors $\mathrm{A}$ and $\mathrm{B}$ mediate an intracellular cyclic guanosine monophosphate-dependent signaling cascade, while the NP receptor C (NPRC; NPR3) facilitates the removal of NPs from circulation (Anand-Srivastava 2005). The discovery that NP receptors are expressed in the adipose tissue of rats and humans opened an area of inquiry into the actions of NPs in fat (Sarzani et al. 1993, 1996), and it was subsequently shown that ANP and BNP stimulate lipolysis in human adipocytes (Lafontan et al. 2008). Recent work on Nprc-global knockout mice shows that these animals have increased ANP, reduced fat depot size, and increased thermogenic gene expression (Bordicchia et al. 2012). Further studies evidenced both ANP and BNP in the regulation of thermogenesis: ANP was shown to mediate the induction of thermogenic genes through the stimulation of a cGMP/p38 MAPK pathway and the constant delivery of BNP to mice resulted in increased energy expenditure and beiging of white adipose tissue (Bordicchia et al. 2012).

\section{Signaling from immune cells}

One consequence of obesity is a change in the macrophage populations seen in adipose tissue from anti-inflammatory M2 macrophages to pro-inflammatory M1 macrophages (Lumeng \& Saltiel 2011). This switch in macrophage populations may contribute to the decrease in thermogenesis because catecholamines produced by M2 macrophages can signal through the $\beta$-ARs to induce thermogenesis (Nguyen et al. 2011, Qiu et al. 2014). Recently, it has been shown that other cells associated with the type 2 immune response, specifically type 2 lymphoid cells, can also contribute to the beiging of fat (Brestoff et al. 2015, Lee et al. 2015). The development of chronic inflammation during obesity leads to upregulation of the noncanonical $\mathrm{NF} \kappa \mathrm{B}$ target, I $\mathrm{B}$ kinase $\varepsilon$ (IKK $\varepsilon$ ) (Chiang et al. 2009). The increase in IKKe results in catecholamine resistance in adipose tissue, which in turn suppresses the induction of UCP1 (Mowers et al. 2013). This is consistent with the observation that an $I k k \varepsilon$-global knockout mouse has less inflammation, increased energy expenditure, and upregulation of thermogenic gene expression in the visceral depot compared with WT animals (Chiang et al. 2009). Treating high fat diet-fed animals with a specific inhibitor of both IKK $\varepsilon$ and the related kinase TBK1 results in reduced lipid deposition in brown adipose tissue and an increase in thermogenic gene expression (Reilly et al. 2013). These studies provide a model in which the development of obesity leads not only to the loss of a thermogenic signal from type 2 inflammatory cells

Published by Bioscientifica Ltd. 
but also to the development of chronic inflammation and subsequent resistance to thermogenic signals.

\section{Myokines (irisin and METRNL)}

Induction of PGC1 $\alpha$ in skeletal muscle has systematic benefits including an increase in energy expenditure and prevention of age-related obesity (Puigserver \& Spiegelman 2003, Wenz et al. 2009). Elevated expression of the protein fibronectin type III domain containing 5 (FNDC5) was seen in a model of skeletal muscle-specific overexpression of PGC1 $\alpha$. Irisin, the cleaved form of FNDC5, is a secreted hormone released after exercise, which stimulates the beiging of white fat (Bostrom et al. 2012, Huh et al. 2012). Recently, irisin has been demonstrated to be not only a myokine but also an adipokine that can be secreted from white fat tissue under certain physiological and pathological conditions (Roca-Rivada et al. 2013). It has been shown that cold exposure increases the levels of circulating irisin, suggesting that shivering may result in irisin release from muscle and therefore providing another potential physiological mechanism by which irisin stimulates beiging (Lee et al. 2014a). In addition to irisin, meteorinlike (METRNL) has also recently been implicated as playing a role in metabolism. METRNL is a hormone that is released from muscle after exercise and from adipose tissue upon cold exposure. Intravenous injections of an adenoviral METRNL construct or direct injection of recombinant protein into mice induces thermogenesis in fat, increases whole-body energy expenditure, and improves glucose tolerance through eosinophil-dependent IL4/IL13 signaling (Rao et al. 2014). The identification and characterization of irisin and METRNL provide a model in which myokines released during exercise influence metabolism. The extent to which myokine signaling contributes to the overall metabolic benefits of exercise and how these signals interact with other exercise-regulated pathways await further study.

\section{Bone morphogenetic proteins}

Bone morphogenetic proteins (BMPs) are members of the TGF $\beta$ superfamily and are involved in multiple biological processes in adipose tissue, including enhancing preadipocyte proliferation (Stewart et al. 2010), inducing adipogenesis (Jin et al. 2006), influencing adipocyte lineage commitment (Huang et al. 2009), and regulating thermogenesis (Tseng et al. 2008, Whittle et al. 2012). BMP7 has been shown to promote brown adipogenesis through the induction of PRDM16 and PGC1 $\alpha$ (Tseng et al. 2008).
Another family member, BMP8b, functions in the CNS to increase sympathetic output and therefore increases the response of thermogenic fat to cold exposure through p38 MAPK and CREB signaling (Whittle et al. 2012). A Bmp8b-global knockout mouse has reduced thermogenic gene expression in adipose tissue compared with controls (Whittle et al. 2012).

\section{Newly discovered factors}

More recently, additional secreted factors important to thermogenic fat biology have been reported (Gnad et al. 2014, Kir et al. 2014, Wang et al. 2014b, Crane et al. 2015, Fang et al. 2015). For want of space, we have briefly discussed only a few of them here.

It has been observed that cachexia, the wasting of adipose and skeletal muscle tissues seen in diseases such as cancer, is associated with the activation of brown fat (Shellock et al. 1986). A recent study has found that the thermogenic program is activated in fat cells treated with the conditioned medium from Lewis lung carcinoma (LLC) cells, a well-characterized model of cachexia (Kir et al. 2014). Global gene expression analysis of LLC cells identified parathyroid hormone-related protein (PTHrP) as regulating the activation of thermogenesis, probably through the cAMP/PKA pathway (Kir et al. 2014). This discovery has begun to provide mechanistic insights into the etiology of the development of cachexia and further studies may suggest treatments that can prevent tissue wasting during disease.

Adenosine has recently been shown to increase lipolysis in primary human and mouse adipocytes (Gnad et al. 2014). Adenosine is released from brown fat upon sympathetic stimulation and can signal brown adipocytes to stimulate thermogenesis. The adenosine receptor $\mathrm{A}_{2 \mathrm{~A}}$ is not highly expressed in white adipose tissue; however, pharmacological activation of $\mathrm{A}_{2 \mathrm{~A}}$ and viral delivery of $A_{2 \mathrm{~A}}$ into the subcutaneous depot of mice both significantly increase beiging (Gnad et al. 2014).

Neuregulin 4 (NRG4), a member of the epidermal growth factor (EGF) family, has been recently discovered to be a secreted factor that is released from brown fat (Wang et al. 2014b). NRG4 binds to ERBB receptors in the liver and its activation inhibits the SREBP1c-lipogenic pathway through trans-repression of the liver X receptor by STAT5. In vivo gain- and loss-of-function studies have shown that NRG4 helps to ameliorate diet-induced obesity and insulin resistance (Wang et al. 2014b). These studies suggest that factors released from brown fat can play a role in the regulation of energy expenditure and systemic metabolism.

Published by Bioscientifica Ltd 


\section{Human thermogenic fat}

While originally it was believed that the only brown fat in humans was found in newborns and was rapidly lost postnatally, analysis of ${ }^{18} \mathrm{~F}$-fluorodeoxyglucose positronemission tomographic and computed tomographic (PET-CT) scans showed that there is active thermogenic fat in some adults (Nedergaard et al. 2007). Biopsies of 'hot' areas indicated by PET-CT scans reveal that the fat tissue in the supraclavicular region, as well as in the neck and paraspinal regions, expresses UCP1 (Cypess et al. 2009, van Marken Lichtenbelt et al. 2009, Saito et al. 2009, Virtanen et al. 2009). The identity of the thermogenic fat in adults remains uncertain. While the thermogenic fat found in babies has the characteristics of classical brown fat, gene expression analyses performed on adult thermogenic fat have shown the presence of genes that are thought to be beige specific (Sharp et al. 2012, Wu et al. 2012, Lidell et al. 2013, Lee et al. 2014b), suggesting that they might be beige fat. Other studies have suggested that human thermogenic fat tissue may be a mixture of brown and beige cells (Cypess et al. 2013, Jespersen et al. 2013).
Recent work has indicated that thermogenic fat may play an important, active, metabolic role in humans (Table 1). Multiple studies have shown that the presence of thermogenic fat is negatively correlated with age and BMI (Cypess et al. 2009, van Marken Lichtenbelt et al. 2009, Saito et al. 2009, Lee et al. 2010, Ouellet et al. 2011). There is an increase in the amount of detectable thermogenic fat in patients who underwent significant weight loss after gastric bypass surgery, suggesting that the decrease in the amount of thermogenic fat seen during obesity can be reversed (Vijgen et al. 2012). It has also been shown that environmental temperature modulates the amount of detectable thermogenic fat in adults (van Marken Lichtenbelt et al. 2009, Saito et al. 2009, Virtanen et al. 2009). Furthermore, acute cold exposure increases resting metabolic rate more in individuals who have thermogenic fat visible on PET-CT scans compared with individuals without detectable thermogenic fat (Yoneshiro et al. 2011a, 2013, Ouellet et al. 2012, Chen et al. 2013, van der Lans et al. 2013), this is in line with reports that there is increased glucose and fatty acid uptake in supraclavicular fat depots in response to cold

Table 1 Thermogenic fat in humans correlates with physiological and environmental factors and influences metabolic parameters

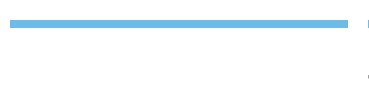

Age

Thermogenic fat

BMI

Negatively correlated

Cold exposure and

environmental

Positively correlated

temperature
4842

24-62

\begin{tabular}{c}
$\begin{array}{c}\text { Sample size } \\
\text { (max) }\end{array}$ \\
\hline 4842
\end{tabular}
of means)

28-62

ㅇํ

$A$

References

Au-Yong et al. (2009), Cypess et al. (2009), Saito et al. (2009), Lee et al. (2010), Pfannenberg et al. (2010), Ouellet et al. (2011), Yoneshiro et al. (2011b), Chen et al. (2013) and Orava et al. (2013)

Au-Yong et al. (2009), Cypess et al. (2009), van Marken Lichtenbelt et al. (2009), Saito et al. (2009), Lee et al. (2010), Pfannenberg et al. (2010), Ouellet et al. (2011), Yoneshiro et al. (2011b), Vijgen et al. (2012), Orava et al. (2013), Yoneshiro et al. (2013) and Matsushita et al. (2014)

Au-Yong et al. (2009), Cypess et al. (2009), van Marken Lichtenbelt et al. (2009), Saito et al. (2009), Virtanen et al. (2009), Orava et al. (2011), Ouellet et al. (2011, 2012), Yoneshiro et al. (2011a), Cypess et al. (2012), Vosselman et al. (2012) and Chen et al. (2013)

\begin{tabular}{|c|c|c|}
\hline $\begin{array}{l}\text { Respiratory exchange } \\
\text { ratio and nonshivering } \\
\text { thermogenesis }\end{array}$ & $\begin{array}{c}\text { Increased by activation } \\
\text { of thermogenic fat }\end{array}$ & 27 \\
\hline $\begin{array}{l}\text { Glucose homeostasis and } \\
\text { insulin sensitivity }\end{array}$ & $\begin{array}{l}\text { Improved by activation } \\
\text { of thermogenic fat }\end{array}$ & 12 \\
\hline
\end{tabular}

van Marken Lichtenbelt et al. (2009), Orava et al. (2011), Yoneshiro et al. (2011a), Vijgen et al. (2012) and van der Lans et al. (2013)

Chondronikola et al. (2014) and Lee et al. (2014c) 
exposure (Orava et al. 2011, Ouellet et al. 2012). Most excitingly, it has recently been shown that the accumulation of thermogenic fat in response to cold exposure results in improvements in insulin sensitivity and glucose homeostasis (Chondronikola et al. 2014, Lee et al. 2014c) as well as a decrease in body weight (Yoneshiro et al. 2013). These studies indicate that human thermogenic fat is a viable target for anti-obesity and anti-diabetic treatments.

\section{Concluding remarks}

In the long pursuit of better understanding and more effective therapeutics for metabolic disease, we have become aware that many of these disorders are polygenic and multifactorial, suggesting that the ultimate solution demands a thorough knowledge of all cell types involved, and of both cell autonomous regulation and intercellular communication. Increasing appreciation has been directed toward the role of adipose tissue in this complicated network. For two decades, since the cloning of leptin (Zhang et al. 1994) and the discovery that fat tissue can generate inflammatory cytokines in obesity (Hotamisligil et al. 1993), the endocrine function of adipose tissue has been studied in detail and is relatively well understood. It has only been in the last decade that researchers and clinicians in the metabolic field have begun to recognize the potential influence of thermogenic fat cells on whole-body metabolism. We have made great advances in our understanding of how these cells are regulated both transcriptionally and by circulating factors and our knowledge of how these cells contribute to human metabolism is growing. Ongoing research is continually uncovering new methods to target these cells and recent studies have begun to show that some therapeutics already in clinical use, such as the mineralocorticoid receptor antagonist spirolactone and the GLP1 receptor agonist liraglutide, may also be able to stimulate thermogenic fat (Armani et al. 2014, Beiroa et al. 2014). With this knowledge, we can hopefully soon develop treatments that target thermogenic fat to fight against obesity and associated conditions.

\section{Declaration of interest}

The authors declare that there is no conflict of interest that could be perceived as prejudicing the impartiality of this review.

\section{Funding}

Work in the Wu laboratory is supported by grants K01DK094824 and R03DK100698 from the National Institute of Diabetes and Digestive and
Kidney Diseases of the National Institutes of Health, a Young Investigator Grant RGY0082/14 from the Human Frontier Science Program, and a Pilot and Feasibility Grant from the Michigan Diabetes Research Center ( $\mathrm{NIH}$ Grant 2P30-DK020572).

\section{Acknowledgements}

The authors thank the members of the Wu lab for valuable discussions and apologize to those whose work we were not able to cite due to space limitations.

\section{References}

Ahmadian M, Suh JM, Hah N, Liddle C, Atkins AR, Downes M \& Evans RM 2013 PPAR $\gamma$ signaling and metabolism: the good, the bad and the future. Nature Medicine 19 557-566. (doi:10.1038/nm.3159)

Akerblad P, Lind U, Liberg D, Bamberg K \& Sigvardsson M 2002 Early B-cell factor $(\mathrm{O} / \mathrm{E}-1)$ is a promoter of adipogenesis and involved in control of genes important for terminal adipocyte differentiation. Molecular and Cellular Biology 22 8015-8025. (doi:10.1128/MCB.22.22.8015-8025.2002)

Anand-Srivastava MB 2005 Natriuretic peptide receptor-C signaling and regulation. Peptides 26 1044-1059. (doi:10.1016/j.peptides.2004.09.023)

Armani A, Cinti F, Marzolla V, Morgan J, Cranston GA, Antelmi A, Carpinelli G, Canese R, Pagotto U, Quarta C et al. 2014 Mineralocorticoid receptor antagonism induces browning of white adipose tissue through impairment of autophagy and prevents adipocyte dysfunction in high-fat-diet-fed mice. FASEB Journal 28 3745-3757. (doi:10.1096/ fj.13-245415)

Au-Yong IT, Thorn N, Ganatra R, Perkins AC \& Symonds ME 2009 Brown adipose tissue and seasonal variation in humans. Diabetes $\mathbf{5 8}$ 2583-2587. (doi:10.2337/db09-0833)

Bachman ES, Dhillon H, Zhang CY, Cinti S, Bianco AC, Kobilka BK \& Lowell BB 2002 BAR signaling required for diet-induced thermogenesis and obesity resistance. Science 297 843-845. (doi:10.1126/science.1073160)

Badman MK, Koester A, Flier JS, Kharitonenkov A \& Maratos-Flier E 2009 Fibroblast growth factor 21-deficient mice demonstrate impaired adaptation to ketosis. Endocrinology 150 4931-4940. (doi:10.1210/ en.2009-0532)

Beiroa D, Imbernon M, Gallego R, Senra A, Herranz D, Villarroya F, Serrano M, Ferno J, Salvador J, Escalada J et al. 2014 GLP-1 agonism stimulates brown adipose tissue thermogenesis and browning through hypothalamic AMPK. Diabetes 63 3346-3358. (doi:10.2337/db14-0302)

Bianco AC, Sheng X \& Silva JE 1988 Triiodothyronine amplifies norepinephrine stimulation of uncoupling protien gene transcription by a mechanism not requiring protein synthesis. Journal of Biological Chemistry 263 18168-18175.

Bordicchia M, Liu D, Amri EZ, Ailhaud G, Dessi-Fulgheri P, Zhang C, Takahashi N, Sarzani R \& Collins S 2012 Cardiac natriuretic peptides act via p38 MAPK to induce the brown fat thermogenic program in mouse and human adipocytes. Journal of Clinical Investigation 122 1022-1036. (doi:10.1172/JCI59701)

Bostrom P, Wu J, Jedrychowski MP, Korde A, Ye L, Lo JC, Rasbach KA, Bostrom EA, Choi JH, Long JZ et al. 2012 A PGC1- $\alpha$-dependent myokine that drives brown-fat-like development of white fat and thermogenesis. Nature 481 463-468. (doi:10.1038/nature10777)

Brestoff JR, Kim BS, Saenz SA, Stine RR, Monticelli LA, Sonnenberg GF, Thome JJ, Farber DL, Lutfy K, Seale P et al. 2015 Group 2 innate lymphoid cells promote beiging of white adipose tissue and limit obesity. Nature 519 242-246. (doi:10.1038/nature14115)

Calo E, Quintero-Estades JA, Danielian PS, Nedelcu S, Berman SD \& Lees JA $2010 \mathrm{Rb}$ regulates fate choice and lineage commitment in vivo. Nature 466 1110-1114. (doi:10.1038/nature09264)

Published by Bioscientifica Ltd. 
Cannon B \& Nedergaard J 2004 Brown adipose tissue: function and physiological significance. Physiological Reviews 84 277-359. (doi:10. 1152/physrev.00015.2003)

Cawthorn WP, Scheller EL, Learman BS, Parlee SD, Simon BR, Mori H, Ning X, Bree AJ, Schell B, Broome DT et al. 2014 Bone marrow adipose tissue is an endocrine organ that contributes to increased circulating adiponectin during caloric restriction. Cell Metabolism 20 368-375. (doi:10.1016/j. cmet.2014.06.003)

Chen KY, Brychta RJ, Linderman JD, Smith S, Courville A, Dieckmann W, Herscovitch P, Millo CM, Remaley A, Lee P et al. 2013 Brown fat activation mediates cold-induced thermogenesis in adult humans in response to a mild decrease in ambient temperature. Journal of Clinical Endocrinology and Metabolism 98 E1218-E1223. (doi:10.1210/jc.2012-4213)

Chiang SH, Bazuine M, Lumeng CN, Geletka LM, Mowers J, White NM, Ma JT, Zhou J, Qi N, Westcott D et al. 2009 The protein kinase IKKe regulates energy balance in obese mice. Cell 138 961-975. (doi:10. 1016/j.cell.2009.06.046)

Chondronikola M, Volpi E, Borsheim E, Porter C, Annamalai P, Enerback S, Lidell ME, Saraf MK, Labbe SM, Hurren NM et al. 2014 Brown adipose tissue improves whole-body glucose homeostasis and insulin sensitivity in humans. Diabetes 63 4089-4099. (doi:10.2337/db14-0746)

Christian M, Kiskinis E, Debevec D, Leonardsson G, White R \& Parker MG 2005 RIP140-targeted repression of gene expression in adipocytes. Molecular and Cellular Biology 25 9383-9391. (doi:10.1128/MCB.25.21. 9383-9391.2005)

Cohen P, Levy JD, Zhang Y, Frontini A, Kolodin DP, Svensson KJ, Lo JC, Zeng X, Ye L, Khandekar MJ et al. 2014 Ablation of PRDM16 and beige adipose causes metabolic dysfunction and a subcutaneous to visceral fat switch. Cell 156 304-316. (doi:10.1016/j.cell.2013.12.021)

Coskun T, Bina HA, Schneider MA, Dunbar JD, Hu CC, Chen Y, Moller DE \& Kharitonenkov A 2008 Fibroblast growth factor 21 corrects obesity in mice. Endocrinology 149 6018-6027. (doi:10.1210/en.2008-0816)

Crane JD, Palanivel R, Mottillo EP, Bujak AL, Wang H, Ford RJ, Collins A, Blumer RM, Fullerton MD, Yabut JM et al. 2015 Inhibiting peripheral serotonin synthesis reduces obesity and metabolic dysfunction by promoting brown adipose tissue thermogenesis. Nature Medicine 21 166-172. (doi:10.1038/nm.3766)

Cypess AM, Lehman S, Williams G, Tal I, Rodman D, Goldfine AB, Kuo FC, Palmer EL, Tseng YH, Doria A et al. 2009 Identification and importance of brown adipose tissue in adult humans. New England Journal of Medicine 360 1509-1517. (doi:10.1056/NEJMoa0810780)

Cypess AM, Chen YC, Sze C, Wang K, English J, Chan O, Holman AR, Tal I, Palmer MR, Kolodny GM et al. 2012 Cold but not sympathomimetics activates human brown adipose tissue in vivo. PNAS 109 10001-10005. (doi:10.1073/pnas.1207911109)

Cypess AM, White AP, Vernochet C, Schulz TJ, Xue R, Sass CA, Huang TL, Roberts-Toler C, Weiner LS, Sze C etal. 2013 Anatomical localization, gene expression profiling and functional characterization of adult human neck brown fat. Nature Medicine 19 635-639. (doi:10.1038/nm.3112)

Dempersmier J, Sambeat A, Gulyaeva O, Paul SM, Hudak CS, Raposo HF, Kwan HY, Kang C, Wong RH \& Sul HS 2015 Cold-inducible Zfp516 activates UCP1 transcription to promote browning of white fat and development of brown fat. Molecular Cell 57 235-246. (doi:10.1016/j. molcel.2014.12.005)

Fang S, Suh JM, Reilly SM, Yu E, Osborn O, Lackey D, Yoshihara E, Perino A, Jacinto S, Lukasheva Y et al. 2015 Intestinal FXR agonism promotes adipose tissue browning and reduces obesity and insulin resistance. Nature Medicine 21 159-165. (doi:10.1038/nm.3760)

Fedorenko A, Lishko PV \& Kirichok Y 2012 Mechanism of fatty-aciddependent UCP1 uncoupling in brown fat mitochondria. Cell $\mathbf{1 5 1}$ 400-413. (doi:10.1016/j.cell.2012.09.010)

Fisher FM, Kleiner S, Douris N, Fox EC, Mepani RJ, Verdeguer F, Wu J, Kharitonenkov A, Flier JS, Maratos-Flier E et al. 2012 FGF21 regulates PGC- $1 \alpha$ and browning of white adipose tissues in adaptive thermogenesis. Genes and Development 26 271-281. (doi:10.1101/gad. 177857.111)
Fu L, John LM, Adams SH, Yu XX, Tomlinson E, Renz M, Williams PM, Soriano R, Corpuz R, Moffat B et al. 2004 Fibroblast growth factor 19 increases metabolic rate and reverses dietary and leptin-deficient diabetes. Endocrinology 145 2594-2603. (doi:10.1210/en.2003-1671)

Fukui Y, Masui S, Osada S, Umesono K \& Motojima K 2000 A new thiazolidinedione, NC-2100, which is a weak PPAR- $\gamma$ activator, exhibits potent antidiabetic effects and induces uncoupling protein 1 in white adipose tissue of KKAy obese mice. Diabetes 49 759-767. (doi:10.2337/ diabetes.49.5.759)

Garcia-Alonso V, Lopez-Vicario C, Titos E, Moran-Salvador E, GonzalezPeriz A, Rius B, Parrizas M, Werz O, Arroyo V \& Claria J 2013 Coordinate functional regulation between microsomal prostaglandin E synthase-1 (mPGES-1) and peroxisome proliferator-activated receptor gamma $(\mathrm{PPAR} \gamma)$ in the conversion of white-to-brown adipocytes. Journal of Biological Chemistry 288 28230-28242. (doi:10.1074/jbc.M113.468603)

Gnad T, Scheibler S, von Kugelgen I, Scheele C, Kilic A, Glode A, Hoffmann LS, Reverte-Salisa L, Horn P, Mutlu S et al. 2014 Adenosine activates brown adipose tissue and recruits beige adipocytes via A2A receptors. Nature 516 395-399. (doi:10.1038/nature13816)

Gray SL, Dalla Nora E, Backlund EC, Manieri M, Virtue S, Noland RC, O'Rahilly S, Cortright RN, Cinti S, Cannon B et al. 2006 Decreased brown adipocyte recruitment and thermogenic capacity in mice with impaired peroxisome proliferator-activated receptor (P465L PPAR $\gamma$ ) function. Endocrinology 147 5708-5714. (doi:10.1210/en.2006-0684)

Guerra C, Roncero C, Porras A, Fernandez M \& Benito M 1996 Triiodothyronine induces the transcription of the uncoupling protein gene and stabilizes its mRNA in fetal rat brown adipocyte primary cultures. Journal of Biological Chemistry 271 2076-2081. (doi:10.1074/ jbc.271.4.2076)

Gupta RK, Arany Z, Seale P, Mepani RJ, Ye L, Conroe HM, Roby YA, Kulaga H, Reed RR \& Spiegelman BM 2010 Transcriptional control of preadipocyte determination by Zfp423. Nature 464 619-623. (doi:10.1038/nature08816)

Hagman J, Belanger C, Travis A, Turck CW \& Grosschedl R 1993 Cloning and functional characterization of early B-cell factor, a regulator of lymphocyte-specific gene expression. Genes and Development $\mathbf{7}$ 760-773. (doi:10.1101/gad.7.5.760)

Hallberg M, Morganstein DL, Kiskinis E, Shah K, Kralli A, Dilworth SM, White R, Parker MG \& Christian M 2008 A functional interaction between RIP140 and PGC-1 $\alpha$ regulates the expression of the lipid droplet protein CIDEA. Molecular and Cellular Biology 28 6785-6795. (doi:10.1128/MCB.00504-08)

Harms MJ, Ishibashi J, Wang W, Lim HW, Goyama S, Sato T, Kurokawa M, Won KJ \& Seale P 2014 Prdm16 is required for the maintenance of brown adipocyte identity and function in adult mice. Cell Metabolism 19 593-604. (doi:10.1016/j.cmet.2014.03.007)

Himms-Hagen J 1989 Role of thermogenesis in the regulation of energy balance in relation to obesity. Canadian Journal of Physiology and Pharmacology 67 394-401. (doi:10.1139/y89-063)

Holland WL, Adams AC, Brozinick JT, Bui HH, Miyauchi Y, Kusminski CM, Bauer SM, Wade M, Singhal E, Cheng CC et al. 2013 An FGF21adiponectin-ceramide axis controls energy expenditure and insulin action in mice. Cell Metabolism 17 790-797. (doi:10.1016/j.cmet.2013.03.019)

Hondares E, Iglesias R, Giralt A, Gonzalez FJ, Giralt M, Mampel T \& Villarroya F 2011 Thermogenic activation induces FGF21 expression and release in brown adipose tissue. Journal of Biological Chemistry 286 12983-12990. (doi:10.1074/jbc.M110.215889)

Hotamisligil G, Shargill N \& Spiegelman B 1993 Adipose expression of tumor necrosis factor- $\alpha$ : direct role in obesity-linked insulin resistance. Science 259 87-91. (doi:10.1126/science.7678183)

Huang H, Song TJ, Li X, Hu L, He Q, Liu M, Lane MD \& Tang QQ 2009 BMP signaling pathway is required for commitment of C3H10T1/2 pluripotent stem cells to the adipocyte lineage. PNAS 106 12670-12675. (doi:10.1073/pnas.0906266106)

Huh JY, Panagiotou G, Mougios V, Brinkoetter M, Vamvini MT, Schneider BE \& Mantzoros CS 2012 FNDC5 and irisin in humans:

Published by Bioscientifica Ltd 
I. Predictors of circulating concentrations in serum and plasma and II. mRNA expression and circulating concentrations in response to weight loss and exercise. Metabolism 61 1725-1738. (doi:10.1016/j.metabol. 2012.09.002)

Itoh N 2014 FGF21 as a hepatokine, adipokine, and myokine in metabolism and diseases. Frontiers in Endocrinology 5 107. (doi:10.3389/ fendo.2014.00107)

Jespersen NZ, Larsen TJ, Peijs L, Daugaard S, Homoe P, Loft A, de Jong J, Mathur N, Cannon B, Nedergaard J et al. 2013 A classical brown adipose tissue mRNA signature partly overlaps with brite in the supraclavicular region of adult humans. Cell Metabolism 17 798-805. (doi:10.1016/j. cmet.2013.04.011)

Jimenez MA, Akerblad P, Sigvardsson M \& Rosen ED 2007 Critical role for Ebf1 and Ebf2 in the adipogenic transcriptional cascade. Molecular and Cellular Biology 27 743-757. (doi:10.1128/MCB.01557-06)

Jin W, Takagi T, Kanesashi SN, Kurahashi T, Nomura T, Harada J \& Ishii S 2006 Schnurri-2 controls BMP-dependent adipogenesis via interaction with Smad proteins. Developmental Cell 10 461-471. (doi:10.1016/j. devcel.2006.02.016)

Jonker JW, Suh JM, Atkins AR, Ahmadian M, Li P, Whyte J, He M, Juguilon H, Yin YQ, Phillips CT et al. 2012 A PPAR $\gamma-F G F 1$ axis is required for adaptive adipose remodelling and metabolic homeostasis. Nature $\mathbf{4 8 5}$ 391-394. (doi:10.1038/nature10998)

Kajimura S, Seale P, Kubota K, Lunsford E, Frangioni JV, Gygi SP \& Spiegelman BM 2009 Initiation of myoblast to brown fat switch by a PRDM16-C/EBP- $\beta$ transcriptional complex. Nature 460 1154-1158. (doi:10.1038/nature08262)

Kharitonenkov A \& Adams AC 2014 Inventing new medicines: the FGF21 story. Molecular Metabolism 3 221-229. (doi:10.1016/j.molmet. 2013.12.003)

Kharitonenkov A, Shiyanova TL, Koester A, Ford AM, Micanovic R, Galbreath EJ, Sandusky GE, Hammond LJ, Moyers JS, Owens RA et al. 2005 FGF-21 as a novel metabolic regulator. Journal of Clinical Investigation 115 1627-1635. (doi:10.1172/JCI23606)

Kiefer FW, Vernochet C, O'Brien P, Spoerl S, Brown JD, Nallamshetty S, Zeyda M, Stulnig TM, Cohen DE, Kahn CR et al. 2012 Retinaldehyde dehydrogenase 1 regulates a thermogenic program in white adipose tissue. Nature Medicine 18 918-925. (doi:10.1038/nm.2757)

Kir S, White JP, Kleiner S, Kazak L, Cohen P, Baracos VE \& Spiegelman BM 2014 Tumour-derived PTH-related protein triggers adipose tissue browning and cancer cachexia. Nature 513 100-104. (doi:10.1038/ nature13528)

Koncarevic A, Kajimura S, Cornwall-Brady M, Andreucci A, Pullen A, Sako D, Kumar R, Grinberg AV, Liharska K, Ucran JA et al. 2012 A novel therapeutic approach to treating obesity through modulation of TGF $\beta$ signaling. Endocrinology 153 3133-3146. (doi:10.1210/en.2012-1016)

Kong X, Banks A, Liu T, Kazak L, Rao RR, Cohen P, Wang X, Yu S, Lo JC, Tseng YH et al. 2014 IRF4 is a key thermogenic transcriptional partner of PGC-1 $\alpha$. Cell 158 69-83. (doi:10.1016/j.cell.2014.04.049)

Lafontan M, Moro C, Berlan M, Crampes F, Sengenes C \& Galitzky J 2008 Control of lipolysis by natriuretic peptides and cyclic GMP. Trends in Endocrinology and Metabolism 19 130-137. (doi:10.1016/j.tem. 2007.11.006)

van der Lans AA, Hoeks J, Brans B, Vijgen GH, Visser MG, Vosselman MJ, Hansen J, Jorgensen JA, Wu J, Mottaghy FM et al. 2013 Cold acclimation recruits human brown fat and increases nonshivering thermogenesis. Journal of Clinical Investigation 123 3395-3403. (doi:10.1172/JCI68993)

Lee P, Greenfield JR, Ho KK \& Fulham MJ 2010 A critical appraisal of the prevalence and metabolic significance of brown adipose tissue in adult humans. American Journal of Physiology. Endocrinology and Metabolism 299 E601-E606. (doi:10.1152/ajpendo.00298.2010)

Lee P, Linderman JD, Smith S, Brychta RJ, Wang J, Idelson C, Perron RM, Werner CD, Phan GQ, Kammula US et al. 2014a Irisin and FGF21 are cold-induced endocrine activators of brown fat function in humans. Cell Metabolism 19 302-309. (doi:10.1016/j.cmet.2013.12.017)
Lee P, Werner CD, Kebebew E \& Celi FS 2014b Functional thermogenic beige adipogenesis is inducible in human neck fat. International Journal of Obesity 38 170-176. (doi:10.1038/ijo.2013.82)

Lee P, Smith S, Linderman J, Courville AB, Brychta RJ, Dieckmann W, Werner CD, Chen KY \& Celi FS 2014c Temperature-acclimated brown adipose tissue modulates insulin sensitivity in humans. Diabetes 63 3686-3698. (doi:10.2337/db14-0513)

Lee M, Odegaard JI, Mukundan L, Qiu Y, Molofsky AB, Nussbaum JC, Yun K, Locksley RM \& Chawla A 2015 Activated type 2 innate lymphoid cells regulate beige fat biogenesis. Cell 160 74-87. (doi:10.1016/j.cell. 2014.12.011)

Lelliott CJ, Medina-Gomez G, Petrovic N, Kis A, Feldmann HM, Bjursell M, Parker N, Curtis K, Campbell M, Hu P et al. 2006 Ablation of PGC-1 $\beta$ results in defective mitochondrial activity, thermogenesis, hepatic function, and cardiac performance. PLoS Biology 4 e369. (doi:10.1371/ journal.pbio.0040369)

Lidell ME, Betz MJ, Dahlqvist Leinhard O, Heglind M, Elander L, Slawik M, Mussack T, Nilsson D, Romu T, Nuutila P et al. 2013 Evidence for two types of brown adipose tissue in humans. Nature Medicine 19 631-634. (doi:10.1038/nm.3017)

Lin Z, Tian H, Lam KS, Lin S, Hoo RC, Konishi M, Itoh N, Wang Y, Bornstein SR, $\mathrm{Xu}$ A et al. 2013 Adiponectin mediates the metabolic effects of FGF21 on glucose homeostasis and insulin sensitivity in mice. Cell Metabolism 17 779-789. (doi:10.1016/j.cmet.2013.04.005)

Lopez M, Varela L, Vazquez MJ, Rodriguez-Cuenca S, Gonzalez CR, Velagapudi VR, Morgan DA, Schoenmakers E, Agassandian K, Lage R et al. 2010 Hypothalamic AMPK and fatty acid metabolism mediate thyroid regulation of energy balance. Nature Medicine 16 1001-1008. (doi:10.1038/nm.2207)

Lumeng CN \& Saltiel AR 2011 Inflammatory links between obesity and metabolic disease. Journal of Clinical Investigation 121 2111-2117. (doi:10.1172/JCI57132)

Madsen L, Pedersen LM, Lillefosse HH, Fjaere E, Bronstad I, Hao Q, Petersen RK, Hallenborg P, Ma T, De Matteis R et al. 2010 UCP1 induction during recruitment of brown adipocytes in white adipose tissue is dependent on cyclooxygenase activity. PLOS ONE 5 e11391. (doi:10.1371/journal. pone.0011391)

Markan KR, Naber MC, Ameka MK, Anderegg MD, Mangelsdorf DJ, Kliewer SA, Mohammadi M \& Potthoff MJ 2014 Circulating FGF21 is liver derived and enhances glucose uptake during refeeding and overfeeding. Diabetes 63 4057-4063. (doi:10.2337/db14-0595)

van Marken Lichtenbelt WD, Vanhommerig JW, Smulders NM, Drossaerts JM, Kemerink GJ, Bouvy ND, Schrauwen P \& Teule GJ 2009 Cold-activated brown adipose tissue in healthy men. New England Journal of Medicine 360 1500-1508. (doi:10.1056/NEJMoa0808718)

Martinez de Mena R, Scanlan TS \& Obregon MJ 2010 The T3 receptor $\beta 1$ isoform regulates UCP1 and D2 deiodinase in rat brown adipocytes. Endocrinology 151 5074-5083. (doi:10.1210/en.2010-0533)

Matsushita M, Yoneshiro T, Aita S, Kameya T, Sugie H \& Saito M 2014 Impact of brown adipose tissue on body fatness and glucose metabolism in healthy humans. International Journal of Obesity $\mathbf{3 8}$ 812-817. (doi:10.1038/ijo.2013.206)

Mercader J, Palou A \& Bonet ML 2010 Induction of uncoupling protein-1 in mouse embryonic fibroblast-derived adipocytes by retinoic acid. Obesity 18 655-662. (doi:10.1038/oby.2009.330)

Mowers J, Uhm M, Reilly SM, Simon J, Leto D, Chiang SH, Chang L \& Saltiel AR 2013 Inflammation produces catecholamine resistance in obesity via activation of PDE3B by the protein kinases IKK\{varepsilon\} and TBK1. eLife 2 e01119. (doi:10.7554/eLife.01119)

Nedergaard J, Bengtsson T \& Cannon B 2007 Unexpected evidence for active brown adipose tissue in adult humans. American Journal of Physiology. Endocrinology and Metabolism 293 E444-E452. (doi:10.1152/ ajpendo.00691.2006)

Nguyen KD, Qiu Y, Cui X, Goh YP, Mwangi J, David T, Mukundan L, Brombacher F, Locksley RM \& Chawla A 2011 Alternatively activated

Published by Bioscientifica Ltd. 
macrophages produce catecholamines to sustain adaptive thermogenesis. Nature 480 104-108. (doi:10.1038/nature10653)

Niederreither K \& Dolle P 2008 Retinoic acid in development: towards an integrated view. Nature Reviews. Genetics 9 541-553. (doi:10.1038/ $\operatorname{nrg} 2340)$

Ogden CL, Carroll MD, Kit BK \& Flegal KM 2014 Prevalence of childhood and adult obesity in the United States, 2011-2012. Journal of the American Medical Association 311 806-814. (doi:10.1001/jama. 2014.732)

Ohno H, Shinoda K, Spiegelman BM \& Kajimura S 2012 PPAR $\gamma$ agonists induce a white-to-brown fat conversion through stabilization of PRDM16 protein. Cell Metabolism 15 395-404. (doi:10.1016/j.cmet. 2012.01.019)

Orava J, Nuutila P, Lidell ME, Oikonen V, Noponen T, Viljanen T, Scheinin M, Taittonen M, Niemi T, Enerback S et al. 2011 Different metabolic responses of human brown adipose tissue to activation by cold and insulin. Cell Metabolism 14 272-279. (doi:10.1016/j.cmet.2011.06.012)

Orava J, Nuutila P, Noponen T, Parkkola R, Viljanen T, Enerback S, Rissanen A, Pietilainen KH \& Virtanen KA 2013 Blunted metabolic responses to cold and insulin stimulation in brown adipose tissue of obese humans. Obesity 21 2279-2287. (doi:10.1002/oby.20456)

Ouellet V, Routhier-Labadie A, Bellemare W, Lakhal-Chaieb L, Turcotte E, Carpentier AC \& Richard D 2011 Outdoor temperature, age, sex, body mass index, and diabetic status determine the prevalence, mass, and glucose-uptake activity of 18F-FDG-detected BAT in humans. Journal of Clinical Endocrinology and Metabolism 96 192-199. (doi:10.1210/jc. 2010-0989)

Ouellet V, Labbe SM, Blondin DP, Phoenix S, Guerin B, Haman F, Turcotte EE, Richard D \& Carpentier AC 2012 Brown adipose tissue oxidative metabolism contributes to energy expenditure during acute cold exposure in humans. Journal of Clinical Investigation 122 545-552. (doi:10.1172/JCI60433)

Owen BM, Ding X, Morgan DA, Coate KC, Bookout AL, Rahmouni K, Kliewer SA \& Mangelsdorf DJ 2014 FGF21 acts centrally to induce sympathetic nerve activity, energy expenditure, and weight loss. Cell Metabolism 20 670-677. (doi:10.1016/j.cmet.2014.07.012)

Patel V, Adya R, Chen J, Ramanjaneya M, Bari MF, Bhudia SK, Hillhouse EW, Tan BK \& Randeva HS 2014 Novel insights into the cardio-protective effects of FGF21 in lean and obese rat hearts. PLOS ONE 9 e87102. (doi:10.1371/journal.pone.0087102)

Petrovic N, Walden TB, Shabalina IG, Timmons JA, Cannon B \& Nedergaard J 2010 Chronic peroxisome proliferator-activated receptor gamma (PPAR $\gamma$ ) activation of epididymally derived white adipocyte cultures reveals a population of thermogenically competent, UCP1-containing adipocytes molecularly distinct from classic brown adipocytes. Journal of Biological Chemistry 285 7153-7164. (doi:10.1074/ jbc.M109.053942)

Pfannenberg C, Werner MK, Ripkens S, Stef I, Deckert A, Schmadl M, Reimold M, Haring HU, Claussen CD \& Stefan N 2010 Impact of age on the relationships of brown adipose tissue with sex and adiposity in humans. Diabetes 59 1789-1793. (doi:10.2337/db10-0004)

Powelka AM, Seth A, Virbasius JV, Kiskinis E, Nicoloro SM, Guilherme A, Tang X, Straubhaar J, Cherniack AD, Parker MG et al. 2006 Suppression of oxidative metabolism and mitochondrial biogenesis by the transcriptional corepressor RIP140 in mouse adipocytes. Journal of Clinical Investigation 116 125-136. (doi:10.1172/JCI26040)

Puigserver P 2005 Tissue-specific regulation of metabolic pathways through the transcriptional coactivator PGC1- $\alpha$. International Journal of Obesity 29(Suppl 1) S5-S9. (doi:10.1038/sj.ijo.0802905)

Puigserver P \& Spiegelman BM 2003 Peroxisome proliferator-activated receptor-gamma coactivator 1 alpha (PGC-1 $\alpha$ ): transcriptional coactivator and metabolic regulator. Endocrine Reviews 24 78-90. (doi:10. 1210/er.2002-0012)

Puigserver P, Vazquez F, Bonet ML, Pico C \& Palou A 1996 In vitro and in vivo induction of brown adipocyte uncoupling protein (thermogenin) by retinoic acid. Biochemical Journal 317 827-833.
Puigserver P, Wu Z, Park CW, Graves R, Wright M \& Spiegelman BM 1998 A cold-inducible coactivator of nuclear receptors linked to adaptive thermogenesis. Cell 92 829-839. (doi:10.1016/S00928674(00)81410-5)

Qiang L, Wang L, Kon N, Zhao W, Lee S, Zhang Y, Rosenbaum M, Zhao Y, $\mathrm{Gu}$ W, Farmer Stephen R et al. 2012 Brown remodeling of white adipose tissue by SirT1-dependent deacetylation of Ppar $\gamma$. Cell 150 620-632. (doi:10.1016/j.cell.2012.06.027)

Qiu Y, Nguyen KD, Odegaard JI, Cui X, Tian X, Locksley RM, Palmiter RD \& Chawla A 2014 Eosinophils and type 2 cytokine signaling in macrophages orchestrate development of functional beige fat. Cell $\mathbf{1 5 7}$ 1292-1308. (doi:10.1016/j.cell.2014.03.066)

Rajakumari S, Wu J, Ishibashi J, Lim HW, Giang AH, Won KJ, Reed RR \& Seale P 2013 EBF2 determines and maintains brown adipocyte identity. Cell Metabolism 17 562-574. (doi:10.1016/j.cmet.2013.01.015)

Rao RR, Long JZ, White JP, Svensson KJ, Lou J, Lokurkar I, Jedrychowski MP, Ruas JL, Wrann CD, Lo JC et al. 2014 Meteorin-like is a hormone that regulates immune-adipose interactions to increase beige fat thermogenesis. Cell 157 1279-1291. (doi:10.1016/j.cell.2014.03.065)

Reilly SM, Chiang SH, Decker SJ, Chang L, Uhm M, Larsen MJ, Rubin JR, Mowers J, White NM, Hochberg I et al. 2013 An inhibitor of the protein kinases TBK1 and IKK- $\varepsilon$ improves obesity-related metabolic dysfunctions in mice. Nature Medicine 19 313-321. (doi:10.1038/nm.3082)

Ribeiro MO, Carvalho SD, Schultz JJ, Chiellini G, Scanlan TS, Bianco AC \& Brent GA 2001 Thyroid hormone - sympathetic interaction and adaptive thermogenesis are thyroid hormone receptor isoform specific. Journal of Clinical Investigation 108 97-105. (doi:10.1172/ JCI200112584)

Ricciotti E \& FitzGerald GA 2011 Prostaglandins and inflammation. Arteriosclerosis, Thrombosis, and Vascular Biology 31 986-1000. (doi:10. 1161/ATVBAHA.110.207449)

Roca-Rivada A, Castelao C, Senin LL, Landrove MO, Baltar J, Belen Crujeiras A, Seoane LM, Casanueva FF \& Pardo M 2013 FNDC5/irisin is not only a myokine but also an adipokine. PLOS ONE 8 e60563. (doi:10.1371/ journal.pone.0060563)

Rosen ED \& Spiegelman BM 2014 What we talk about when we talk about fat. Cell 156 20-44. (doi:10.1016/j.cell.2013.12.012)

Saito M, Okamatsu-Ogura Y, Matsushita M, Watanabe K, Yoneshiro T, Nio-Kobayashi J, Iwanaga T, Miyagawa M, Kameya T, Nakada K et al. 2009 High incidence of metabolically active brown adipose tissue in healthy adult humans: effects of cold exposure and adiposity. Diabetes 58 1526-1531. (doi:10.2337/db09-0530)

Sarzani R, Paci VM, Dessi-Fulgheri P, Espinosa E \& Rappelli A 1993 Comparative analysis of atrial natriuretic peptide receptor expression in rat tissues. Journal of Hypertension. Supplement 11 S214-S215.

Sarzani R, Dessi-Fulgheri P, Paci VM, Espinosa E \& Rappelli A 1996 Expression of natriuretic peptide receptors in human adipose and other tissues. Journal of Endocrinological Investigation 19 581-585. (doi:10.1007/BF03349021)

Scheller EL \& Rosen CJ 2014 What's the matter with MAT? Marrow adipose tissue, metabolism, and skeletal health. Annals of the New York Academy of Sciences 1311 14-30. (doi:10.1111/nyas.12327)

Scime A, Grenier G, Huh MS, Gillespie MA, Bevilacqua L, Harper ME \& Rudnicki MA $2005 \mathrm{Rb}$ and p107 regulate preadipocyte differentiation into white versus brown fat through repression of PGC-1 $\alpha$. Cell Metabolism 2 283-295. (doi:10.1016/j.cmet.2005.10.002)

Seale P, Kajimura S, Yang W, Chin S, Rohas LM, Uldry M, Tavernier G, Langin D \& Spiegelman BM 2007 Transcriptional control of brown fat determination by PRDM16. Cell Metabolism 6 38-54. (doi:10.1016/j. cmet.2007.06.001)

Seale P, Bjork B, Yang W, Kajimura S, Chin S, Kuang S, Scime A, Devarakonda S, Conroe HM, Erdjument-Bromage H et al. 2008 PRDM16 controls a brown fat/skeletal muscle switch. Nature $\mathbf{4 5 4} 961-967$. (doi:10.1038/nature07182)

Seale P, Conroe HM, Estall J, Kajimura S, Frontini A, Ishibashi J, Cohen P, Cinti S \& Spiegelman BM 2011 Prdm16 determines the thermogenic

Published by Bioscientifica Ltd. 
program of subcutaneous white adipose tissue in mice. Journal of Clinical Investigation 121 96-105. (doi:10.1172/JCI44271)

Sharp LZ, Shinoda K, Ohno H, Scheel DW, Tomoda E, Ruiz L, Hu H, Wang L, Pavlova Z, Gilsanz V et al. 2012 Human BAT possesses molecular signatures that resemble beige/brite cells. PLOS ONE 7 e49452. (doi:10.1371/journal.pone.0049452)

Shellock FG, Riedinger MS \& Fishbein MC 1986 Brown adipose tissue in cancer patients: possible cause of cancer-induced cachexia. Journal of Cancer Research and Clinical Oncology 111 82-85. (doi:10.1007/ BF00402783)

Stewart A, Guan H \& Yang K 2010 BMP-3 promotes mesenchymal stem cell proliferation through the TGF- $\beta$ /activin signaling pathway. Journal of Cellular Physiology 223 658-666. (doi:10.1002/jcp.22064)

Tontonoz P, Hu E \& Spiegelman BM 1994 Stimulation of adipogenesis in fibroblasts by PPAR $\gamma 2$, a lipid-activated transcription factor. Cell 79 1147-1156. (doi:10.1016/0092-8674(94)90006-X)

Tseng YH, Kokkotou E, Schulz TJ, Huang TL, Winnay JN, Taniguchi CM, Tran TT, Suzuki R, Espinoza DO, Yamamoto Y et al. 2008 New role of bone morphogenetic protein 7 in brown adipogenesis and energy expenditure. Nature 454 1000-1004. (doi:10.1038/nature07221)

Uldry M, Yang W, St-Pierre J, Lin J, Seale P \& Spiegelman BM 2006 Complementary action of the PGC-1 coactivators in mitochondrial biogenesis and brown fat differentiation. Cell Metabolism 3 333-341. (doi:10.1016/j.cmet.2006.04.002)

Vegiopoulos A, Muller-Decker K, Strzoda D, Schmitt I, Chichelnitskiy E, Ostertag A, Berriel Diaz M, Rozman J, Hrabe de Angelis M, Nusing RM et al. 2010 Cyclooxygenase- 2 controls energy homeostasis in mice by de novo recruitment of brown adipocytes. Science 328 1158-1161. (doi:10.1126/science.1186034)

Vijgen GH, Bouvy ND, Teule GJ, Brans B, Hoeks J, Schrauwen P \& van Marken Lichtenbelt WD 2012 Increase in brown adipose tissue activity after weight loss in morbidly obese subjects. Journal of Clinical Endocrinology and Metabolism 97 E1229-E1233. (doi:10.1210/ jc.2012-1289)

Villanueva CJ, Waki H, Godio C, Nielsen R, Chou WL, Vargas L, Wroblewski K, Schmedt C, Chao LC, Boyadjian R et al. 2011 TLE3 is a dual-function transcriptional coregulator of adipogenesis. Cell Metabolism 13 413-427. (doi:10.1016/j.cmet.2011.02.014)

Villanueva CJ, Vergnes L, Wang J, Drew BG, Hong C, Tu Y, Hu Y, Peng X, Xu F, Saez E et al. 2013 Adipose subtype-selective recruitment of TLE3 or Prdm 16 by PPAR $\gamma$ specifies lipid storage versus thermogenic gene programs. Cell Metabolism 17 423-435. (doi:10.1016/j.cmet. 2013.01.016)

Virtanen KA, Lidell ME, Orava J, Heglind M, Westergren R, Niemi T, Taittonen M, Laine J, Savisto NJ, Enerback S et al. 2009 Functional brown adipose tissue in healthy adults. New England Journal of Medicine 360 1518-1525. (doi:10.1056/NEJMoa0808949)

Vosselman MJ, van der Lans AA, Brans B, Wierts R, van Baak MA, Schrauwen P \& van Marken Lichtenbelt WD 2012 Systemic $\beta$-adrenergic stimulation of thermogenesis is not accompanied by brown adipose tissue activity in humans. Diabetes $613106-3113$. (doi:10.2337/db12-0288)

Wang W, Kissig M, Rajakumari S, Huang L, Lim HW, Won KJ \& Seale P $2014 a$ Ebf2 is a selective marker of brown and beige adipogenic precursor cells. PNAS 111 14466-14471. (doi:10.1073/pnas. 1412685111)

Wang GX, Zhao XY, Meng ZX, Kern M, Dietrich A, Chen Z, Cozacov Z, Zhou D, Okunade AL, Su X et al. 2014b The brown fat-enriched secreted factor Nrg4 preserves metabolic homeostasis through attenuation of hepatic lipogenesis. Nature Medicine 20 1436-1443. (doi:10.1038/ nm.3713)

Wenz T, Rossi SG, Rotundo RL, Spiegelman BM \& Moraes CT 2009 Increased muscle PGC- $1 \alpha$ expression protects from sarcopenia and metabolic disease during aging. PNAS 106 20405-20410. (doi:10.1073/ pnas.0911570106)

Whittle AJ, Carobbio S, Martins L, Slawik M, Hondares E, Vazquez MJ, Morgan D, Csikasz RI, Gallego R, Rodriguez-Cuenca S et al. 2012 BMP8B increases brown adipose tissue thermogenesis through both central and peripheral actions. Cell 149 871-885. (doi:10.1016/j.cell.2012.02.066)

Wilson-Fritch L, Nicoloro S, Chouinard M, Lazar MA, Chui PC, Leszyk J, Straubhaar J, Czech MP \& Corvera S 2004 Mitochondrial remodeling in adipose tissue associated with obesity and treatment with rosiglitazone. Journal of Clinical Investigation 114 1281-1289. (doi:10.1172/ JCI200421752)

Wu J, Bostrom P, Sparks LM, Ye L, Choi JH, Giang AH, Khandekar M, Virtanen KA, Nuutila P, Schaart G et al. 2012 Beige adipocytes are a distinct type of thermogenic fat cell in mouse and human. Cell $\mathbf{1 5 0}$ 366-376. (doi:10.1016/j.cell.2012.05.016)

Yadav H, Quijano C, Kamaraju AK, Gavrilova O, Malek R, Chen W, Zerfas P, Zhigang D, Wright EC, Stuelten C et al. 2011 Protection from obesity and diabetes by blockade of TGF- $\beta /$ Smad3 signaling. Cell Metabolism 14 67-79. (doi:10.1016/j.cmet.2011.04.013)

Ye L, Wu J, Cohen P, Kazak L, Khandekar MJ, Jedrychowski MP, Zeng X, Gygi SP \& Spiegelman BM 2013 Fat cells directly sense temperature to activate thermogenesis. PNAS 110 12480-12485. (doi:10.1073/pnas. 1310261110)

Yen PM 2001 Physiological and molecular basis of thyroid hormone action. Physiological Reviews 81 1097-1142.

Yoneshiro T, Aita S, Matsushita M, Kameya T, Nakada K, Kawai Y \& Saito M $2011 a$ Brown adipose tissue, whole-body energy expenditure, and thermogenesis in healthy adult men. Obesity 19 13-16. (doi:10.1038/ oby.2010.105)

Yoneshiro T, Aita S, Matsushita M, Okamatsu-Ogura Y, Kameya T, Kawai Y, Miyagawa M, Tsujisaki M \& Saito M 2011b Age-related decrease in coldactivated brown adipose tissue and accumulation of body fat in healthy humans. Obesity 19 1755-1760. (doi:10.1038/oby.2011.125)

Yoneshiro T, Aita S, Matsushita M, Kayahara T, Kameya T, Kawai Y, Iwanaga T \& Saito M 2013 Recruited brown adipose tissue as an antiobesity agent in humans. Journal of Clinical Investigation 123 3404-3408. (doi:10.1172/JCI67803)

Zamani N \& Brown CW 2011 Emerging roles for the transforming growth factor- $\beta$ superfamily in regulating adiposity and energy expenditure. Endocrine Reviews 32 387-403. (doi:10.1210/er.2010-0018)

Zhang Y, Proenca R, Maffei M, Barone M, Leopold L \& Friedman JM 1994 Positional cloning of the mouse obese gene and its human homologue. Nature 372 425-432. (doi:10.1038/372425a0)

Zhao XY, Li S, Wang GX, Yu Q \& Lin JD 2014 A long noncoding RNA transcriptional regulatory circuit drives thermogenic adipocyte differentiation. Molecular Cell 55 372-382. (doi:10.1016/j.molcel.2014. 06.004)

Ziouzenkova O, Orasanu G, Sharlach M, Akiyama TE, Berger JP, Viereck J, Hamilton JA, Tang G, Dolnikowski GG, Vogel S et al. 2007

Retinaldehyde represses adipogenesis and diet-induced obesity. Nature Medicine 13 695-702. (doi:10.1038/nm1587)

Zois NE, Bartels ED, Hunter I, Kousholt BS, Olsen LH \& Goetze JP 2014 Natriuretic peptides in cardiometabolic regulation and disease. Nature Reviews. Cardiology 11 403-412. (doi:10.1038/nrcardio.2014.64)

Received in final form 9 March 2015

Accepted 23 March 2015

Accepted Preprint published online 24 March 2015 http://joe.endocrinology-journals.org

DOI: 10.1530/JOE-15-0026
(C) 2015 Society for Endocrinology Printed in Great Britain
Published by Bioscientifica Ltd. 